\title{
SUPERVISI BERKALA DALAM UPAYA MENINGKATKAN PENGELOLAAN LEMBAGA PENDIDIKAN ANAK USIA DINI (PAUD) SE KECAMATAN DRIYOREJO TAHUN 2018
}

\author{
Hartono \\ Dinas Pendidikan Kecamatan Driyorejo, Gresik \\ hartonogrsk@gmail.com
}

\begin{abstract}
ABSTRAK
Salah satu upaya peningkatan mutu pendidikan anak usia dini adalah melalui kegiatan supervisi oleh Penilik. Saat peneliti melakukan wawancara dan pengamatan, permasalahan yang ditemui di lapangan adalah supervisi PAUD yang dilakukan oleh Penilik belum dilaksanakan secara maksimal. Ditemukan, penilik yang melakukan supervisi PAUD tidak mempunyai kualifikasi PAUD yang mengakibatkan kurangnya pemahaman Penilik pada penyelenggaraan PAUD. Pelaksanaan supervisi tersebut juga belum secara rutin dilakukan oleh Penilik. Hal ini tentu saja dapat menghambat peningkatan mutu pendidikan. Penelitian tentang Pelaksanaan Supervisi PAUD oleh Penilik Dinas Pendidikan Kecamatan Driyorejo diharapkan mampu memberi kontribusi maksimal terhadap pelaksanaan supervisi PAUD sehingga dapat meningkatkan mutu pembelajaran PAUD.

Metode penelitian yang digunakan adalah kualitatif deskriptif dengan menggambarkan pelaksanaan supervisi PAUD. Subjek dalam penelitian ini adalah Penilik sekolah Dinas Pendidikan Kecamatan Driyorejo, kepala sekolah dan guru Himpaudi. Teknik pengumpulan data yang digunakan adalah observasi, wawancara dan dokumentasi. Penelitian ini membahas tentang pelaksanaan supervisi PAUD oleh Penilik Dinas Pendidikan Kecamatan Driyorejo yang meliputi supervisi manajerial dan supervisi akademik, serta teknik-teknik yang digunakan Penilik dalam melaksanakan kegiatan supervisi manajerial dan supervisi akademik.
\end{abstract}

Katakunci : Supervisi, Pendidikan Anak Usia Dini, Penilik

\section{ABSTRACT}

One of the efforts to improve the quality of early childhood education is through supervision activities by the Supervisor. When researchers conduct interviews and observations, the problems encountered in the field are PAUD supervision carried out by the Supervisor has not been carried out optimally. It was found, the overseers who supervised PAUD did not have PAUD qualifications which resulted in a lack of Oversight understanding in the implementation of ECD. The implementation of the supervision has also not been routinely carried out by the Overseer. This of course can hinder the improvement of the quality of education. Research on the Implementation of PAUD Supervision by Oversight Offices of the Driyorejo District Education Office is expected to be able to contribute maximally to PAUD supervision so that it can improve the quality of PAUD learning.

The research method used is descriptive qualitative by describing the implementation of PAUD supervision. The subjects in this study were school supervisors at the Driyorejo Subdistrict Education Office, headmaster and Himpaudi teacher. Data collection techniques used were observation, interviews and documentation. This study discusses the supervision of ECD by Driyorejo Subdistrict Education Supervisor, which includes managerial supervision and academic supervision, as well as techniques used by Oversighters in carrying out managerial supervision and academic supervision activities.

Keywords: Supervision, Early Childhood Education, Oversight 


\section{PENDAHULUAN}

Pendidikan merupakan usaha sadar dan terencana untuk mewujudkan suasana belajar dan proses pembelajaran agar peserta didik secara aktif mengembangkan potensi dirinya untuk memiliki kekuatan spiritual keagamaan, pengendalian diri, kepribadian, kecerdasan, akhlak mulia, serta keterampilan yang diperlukan dirinya, masyarakat, bangsa dan negara yang sesuai dengan UndangUndang RI No. 20 Tahun 2003 pasal 1 ayat 1. Pendidikan memiliki kedudukan dan peranan yang sangat penting dalam pembangunan di segala bidang karena melalui pendidikan akan membentuk sumber daya manusia yang baik. Sehingga mampu menjawab berbagai tantangan kemajuan bangsa dan negara di masa mendatang.

Pendidikan bertujuan untuk mencerdaskan kehidupan bangsa dan meningkatkan mutu sumber daya manusia sebagai upaya dalam mengembangkan dan memajukan potensi bangsa dan negara yang siap mengikuti perkembangan jaman. Pendidikan Anak Usia Dini (PAUD) adalah penyelenggaraan pendidikan pada tingkat awal. Pendidikan anak usia dini adalah suatu upaya pembinaan yang ditujukan kepada anak sejak lahir sampai dengan usia enam tahun yang dilakukan melalui pemberian rangsangan pendidikan untuk membantu pertumbuhan dan perkembangan jasmani dan rohani agar anak memiliki kesiapan dalam memasuki ke jenjang pendidikan yang lebih lanjut.

Pendidikan anak usia dini merupakan pendidikan awal yang berperan penting dalam kehidupan anak. Keberhasilan pendidikan pada jenjang berikutnya ditentukan oleh kualitas pendidikan anak usia dini, sehingga diperlukan adanya penjaminan dan peningkatan mutu pendidikan tersebut. Guru serta pengelolaan sekolah yang baik dapat mempengaruhi peningkatkan keberhasilan proses pembelajaran dan mutu pendidikan. Proses belajar mengajar di sekolah merupakan inti dari proses pendidikan secara keseluruhan dikarenakan guru sebagai peranan utama. Atas dasar inilah pembinaan pada guru dirasa sangat penting agar dapat meningkatkan mutu pembelajaran dan mutu pendidikan secara keseluruhan.

Peningkatkan mutu pendidikan harus diawali dengan meningkatkan mutu sekolah yang meliputi guru, kepala sekolah dan pengawai sekolah lainnya. Salah satu upaya peningkatan mutu pendidikan tersebut dapat dilakukan melalui pelaksanaan supervisi. Supervisi secara sederhana dapat diartikan sebagai tindakan untuk memberikan bantuan dan perbaikan. Supervisi dilakukan dalam bentuk pembinaan yang direncanakan untuk membantu para guru dan pegawai sekolah untuk 
melakukan pekerjaan mereka secara efektif.

Kegiatan pokok supervisi pendidikan adalah pembinaan terhadap sekolah pada umumnya dan pembinaan guru pada khususnya agar kualitas pembelajaran meningkat. Supervisi pada pendidikan anak usia dini adalah suatu upaya pemberian bantuan dan pembinaan kepada guru dan kepala sekolah dalam meningkatkan mutu pembelajaran pada pendidikan anak usia dini. Arikunto (2004:5) membedakan konsep supervisi menjadi dua bagian yaitu supervisi akademik dan supervisi manajerial. Supervisi akademik adalah supervisi yang menitikberatkan pengamatan pada masalah akademik yaitu yang langsung berada dalam lingkup kegiatan pembelajaran yang dilakukan oleh guru. Sedangkan supervisi manajerial adalah supervisi yang menitikberatkan pada aspekaspek administrasi yang berfungsi sebagai pendukung terlaksananya pembelajaran.

Supervisi dilakukan oleh supervisor, supervisor dalam dunia pendidikan terdiri dari kepala sekolah dan pengawas/penilik sekolah. Pengawas sekolah merupakan pegawai negeri sipil yang diberi tugas, tanggung jawab, dan wewenang secara penuh oleh pejabat yang berwenang untuk melakukan penilaian dan pembinaan dari segi teknis pendidikan dan administratif pada satuan pendidikan pra sekolah, sekolah dasar, dan sekolah menengah. Pengawas sekolah adalah salah satu tenaga kependidikan yang bertugas memberikan pengawasan agar tenaga pendidik dan tenaga kependidikan lainnya dapat menjalankan tugasnya dengan baik. Sebagai salah satu unsur dari tenaga kependidikan, pengawas sekolah mempunyai peran yang sangat penting dan strategis dari keseluruhan upaya meningkatkan mutu dan kinerja sekolah.

Supervisi manajerial dan supervisi akademik oleh pengawas sekolah merupakan usaha yang dilakukan seorang pengawas untuk memperbaiki pola kerja dan kinerja sekolah termasuk kinerja guru, sehingga dapat berpengaruh secara positif terhadap proses dan hasil belajar mengajar serta kualitas pendidikan. Supervisi membantu sekolah untuk mengidentifikasi permasalahan sekolah dan mencoba menemukan pemecahannya. Pada tingkat kelas atau manajemen pembelajaran, supervisi membantu guru menyadari potensi yang dimilikinnya dan mengetahui bagaimana cara mengajar yang efektif. Bagi kepala sekolah, supervisi membantu memaksimalkan peran kepala sekolah dalam kepemimpinan atau manajemen pendidikan di sekolah.

Pengawas sekolah pada pendidikan anak usia dini disebut dengan pengawas/penilik PAUD. 
Pengawas/penilik PAUD merupakan pengawas sekolah yang berperan sebagai salah satu komponen dalam sistem pendidikan yang diberikan tanggung jawab dan wewenang secara penuh oleh pejabat yang berwenang untuk melakukan tugas pengawasan pendidikan di lembaga PAUD dengan melaksanakan pembinaan-pembinaan baik dari segi teknis pendidikan dan administrasi pada masing-masing lembaga PAUD tersebut.

\begin{tabular}{lrr}
\multicolumn{1}{c}{ Tugas pokok dari } \\
pengawas/penilik PAUD adalah \\
melakukan penilaian, pemantauan \\
serta pembinaan & dengan
\end{tabular}
melaksanakan fungsi-fungsi supervisi, baik supervisi akademik maupun supervisi manajerial, berupa pemantauan, penilaian, dan pembinaan pada lembaga pendidikan anak usia dini dengan tujuan untuk meningkatkan mutu pembelajaran dan mutu pada pengelolaan lembaga pendidikan tersebut. Kegiatan pemantauan, penilaian dan pembinaan dilakukan oleh pengawas/penilik PAUD secara rutin dan berkelanjutan pada lembaga PAUD yang menjadi binaannya. Dengan adanya kegiatan tersebut yang dilakukan secara rutin dan berkelanjutan maka pengawas diharapkan dapat membantu serta memperbaiki mutu pendidikan secara keseluruhan sesuai dengan kebutuhan dari lembaga PAUD yang menjadi binaannya.
Pengawas/penilik

PAUD didudukkan pada peran penting dan strategis dalam penjaminan mutu pendidikan. Melalui peran yang diberikan pengawas/penilik PAUD untuk membina dan memantau pelaksanaan 8 Standar Nasional Pendidikan, serta melalui peran pengawas sekolah untuk membimbing, melatih dan menilai profesional guru diharapkan mutu pengelolaan sekolah dan pelaksanaan pembelajaran akan terus meningkat yang bermuara kepada peningkatan mutu pendidikan yang baik.

Dari paparan di atas maka dapat diketahui bahwa keberadaan pengawas/penilik PAUD dalam melakukan supervisi adalah untuk memperbaiki dan meningkatkan proses pembelajaran baik dari segi pendidik maupun dari segi administrasi pendidikan juga memiliki fungsi dalam rangka memperbaiki kualitas pendidikan. Pengawas/penilik PAUD sangat berperan penting dalam upaya peningkatan mutu pendidikan. Keberadaan pengawas sekolah memberikan kontribusi pada peningkatan mutu pendidikan baik dari segi mutu pembelajaran di kelas maupun dari segi pengelolaan sekolah.

Namun dalam kenyataannya dilapangan, supervisi yang dilakukan pengawas sekolah belum dilakukakan sesuai dengan harapan. Berdasarkan hasil wawancara dan observasi yang 
telah peneliti lakukan sebelumnya kepada pengawas sekolah di Dinas Pendidikan Kecamatan Driyorejo Kabupaten Gresik, menurut penuturan dari pengawas sekolah bahwa supervisi pada PAUD dilakukan oleh pengawas dan penilik PNFI. Pengawas sekolah yang melakukan supervisi pada PAUD (TK) adalah pengawas TK/PAUD, sedangkan pengawas pada kelompok bermain (KB) adalah penilik PAUD.

Pelaksanaan supervisi pada TK dikategorikan sama dengan supervisi PAUD, sehingga supervisi TK dimasukkan ke dalam supervisi PAUD, tidak adanya pengawas yang melakukan supervisi pada TK secara khusus di wilayah Gresik baik di Kecamatan Driyorejo maupun di Kabupaten Gresik sendiri. TK merupakan jenjang pendidikan untuk anak usia dini yang bersifat formal maka dikategorikan yang sama dengan PAUD yang juga merupakan jenjang pendidikan formal. Sehingga pelaksanaan supervisi TK di wilayah Kecamatan Driyorejo dikategorikan dalam hal kepengawasan, perencanaan serta pelaksanaannya digabung menjadi satu dengan pelaksanaan supervisi PAUD, padahal penyelenggaraan TK dan PAUD jelas berbeda.

Pengawas TK/PAUD yang melakukan supervisi pada TK bukan dari guru atau kepala PAUD melainkan dari guru ataupun kepala sekolah dasar. Hal ini berarti pengawas TK/PAUD yang berada di kecamatan Driyorejo belum sesuai dengan standar pengawas PAUD. Akibatnya mereka yang bertugas menjadi pengawas TK/PAUD kurang mengetahui dan memahami penyelenggaraan PAUD, sehingga supervisi yang dilakukan kurang berjalan optimal.

Kinerja pengawas TK/PAUD pada kecamatan Driyorejo sendiri belum maksimal. Kurang maksimalnya kinerja pengawas TK/PAUD tersebut dikarenakan kompetensi yang harus dimiliki pengawas TK/PAUD masih lemah. Supervisi yang dilakukan pengawas TK/PAUD masih dominan pada bidang administrasinya saja. Kegiatan supervisi tersebut masih banyak yang hanya berupa penilaian pada kinerja kepala sekolah dan kelengkapan sekolah. Pengawas TK/PAUD belum banyak memberikan pembinaan yang terkait dengan pembelajaran di kelas. Cara yang digunakan oleh pengawas TK/PAUD dalam melakukan supervisi masih sama, pengawas belum melakukan strategi dan inovasi baru dalam melakukan tugasnya. Pengawas TK/PAUD hanya datang dan berkunjung padasekolah, kegiatan pembinaan terhadap guruguru dalam meningkatkan profesionalitasnya tidak dilakukan secara berkelanjutan dan tidak intensif. Justru dalam supervisi yang lebih dominan ditonjolkan adalah aspek penilaian terhadap kinerja sekolah dan guru. 


$\begin{array}{lll}\text { Dari uraian yang telah } & \text { yang dimaksud dalam penelitian ini } \\ \text { dijabarkan di atas maka peneliti } & \begin{array}{l}\text { adalah kegiatan pemberian bantuan } \\ \text { tertarik meneliti mengenai gambaran }\end{array} & \begin{array}{l}\text { dan pembinaan kepada guru dan } \\ \text { dari pelaksanaan supervisi PAUD oleh }\end{array} \\ \text { kepala sekolah dalam meningkatkan } \\ \text { pengawas TK/PAUD di Dinas } & \text { mutu pembelajaran di sekolah, } \\ \text { Pendidikan Kecamatan Driyorejo } & \text { Kegiatan supervisi dilakukan oleh } \\ \text { Kabupaten Gresik yang berfokus } & \text { pengawas sekolah. Subjek dalam } \\ \text { pada penyelenggaraan TK sebagai } & \text { penelitian ini adalah pengawas } \\ \text { salah satu bentuk layanan dari PAUD. } & \text { TK/PAUD Dinas Pendidikan } \\ \text { Di Kecamatan Driyorejo terdapat 25 } & \text { Kecamatan Driyorejo. }\end{array}$

PAUD (TK) yang dibina dalam empat wilayah binaan yaitu daerah binaan I, daerah binaan II, daerah binaan III, dan daerah binaan IV. Masingmasing daerah binaan mempunyai satu pengawas TK/PAUD yang melakukan tugas supervisi pada TK dan PAUD.

\section{Fokus Masalah}

Fokus Penelitian pada dasarnya adalah masalah yang bersumber dari pengalaman peneliti atau melalui pengetahuan yang diperoleh melalui keputusan ilmiah maupun keputusan lainnya (Moleong, 2008: 65). Agar tidak menimbulkan kesalahpahaman terhadap informasi yang disampaikan maka peneliti fokus pada pelaksanaan supervisi oleh pengawas Dinas Pendidikan kecamatan Driyorejo di PAUD di Kabupaten Gresik.

\section{Batasan Masalah}

Peneliti membatasi permasalahan dalam penelitian ini untuk menghindari kesalahpahamaan pembaca karena bahasan mengenai supevisi yang terlalu luas. Supervisi

\section{Rumusan Masalah}

Masalah yang dirumuskan dalam penelitian ini adalah sebagai berikut:
1. Bagaimana
pelaksanaan
supervisi manajerial oleh
pengawas Dinas Pendidikan
Kecamatan Driyorejo di PAUD
di Kabupaten Gresik?
2. Bagaimana pelaksanaan supervisi akademik oleh pengawas Dinas Pendidikan Kecamatan Driyorejo di PAUD di Kabupaten Gresik?

3. Teknik apa saja yang digunakan dalam melaksanakan supervisi oleh pengawas Dinas $\begin{array}{ll}\text { Pendidikan } & \text { Kecamatan } \\ \text { Driyorejo di PAUD Kabupaten } & \\ \text { Gresik? } & \end{array}$

\section{Tujuan Penelitian}

Berdasarkan rumusan masalah tersebut, maka tujuan yang ingin dicapai peneliti dalam penelitian ini adalah sebagai berikut:

1. Untuk mengetahui pelaksanaan supervisi manajerial oleh pengawas Dinas Pendidikan 
Kecamatan Driyorejo di PAUD

di Kabupaten Gresik.

2. Untuk mengetahui pelaksanaan supervisi akademik oleh pengawas Dinas Pendidikan Kecamatan Gresik di PAUD di Kabupaten Gresik.

3. Untuk mengetahui teknik yang digunakan dalam pelaksanaan supervisi di PAUD di Kabupaten Gresik.

\section{Manfaat Penelitian}

1. Manfaat Teoritis Penelitian ini dapat memberikan sumbangan pemikiran maupun pengetahuan dan dapat dijadikan sebagai bahan kajian bagi pembaca mengenai pelaksanaan supervisi PAUD oleh pengawas.

2. Manfaat Praktis

\section{a. Bagi Pengawas Sekolah}

Sebagai bahan masukan dalam meningkatkan kinerja pengawasan pada PAUD khususnya TK serta sebagai bahan kajian lebih lanjut bagi pengambilan kebijakan yang berhubungan dengan pengawasan sekolah.

b. Bagi Guru Dapat menambah ilmu pengetahuan dan wawasan mengenai pelaksanaan supervisi PAUD oleh pengawas.

C. Bagi penulis

Untuk menambah dan memperluas pengetahuan mengenai pelaksanaan supervisi
PAUD oleh pengawas serta dapat dijadikan sebagai pedoman untuk kegiatan penelitian yang sejenis pada waktu yang akan datang.

\section{METODOLOGI PENELITIAN}

Pendekatan Penelitian

Pendekatan yang digunakan
dalam penelitian ini adalah
pendekatan kualitatif. Metode
penelitian kualitatif adalah metode penelitian yang berlandaskan pada filsafat postpositive, digunakan untuk meneliti pada kondisi objek yang alamiah, (sebagai lawannya adalah eksperimen) dimana peneliti adalah sebagai instrument kunci, teknik pengumpulan data dilakukan secara trianggulasi (gabungan), analisis data bersifat induktif atau kualitatif, dan hasil penelitian kualitatif lebih menekankan makna dari pada generalisasi (Sugiyono, 2010: 15).

Penelitian ini akan menggambarkan atau mendeskripsikan tentang pelaksanaan supervisi pendidikan anak usia dini (PAUD) yang dilakukan oleh pengawas Dinas Pendidikan Kecamatan Driyorejo Di Himpaudi.

\section{Sumber Data Penelitian}

Sumber data dalam penelitian adalah subjek dari mana data dapat diperoleh. Menurut Moleong (2011: 157) sumber data utama dalam peneltian kualitatif adalah kata- kata dan tindakan, selebihnya adalah data tambahan seperti dokumen dan lain- 
lain. Adapun sumber data dalam penelitian ini adalah sebagai berikut:

\section{Data primer}

Data primer adalah sumber data yang diperoleh secara langsung dari beberapa informan di lapangan melalui wawancara dan observasi. Data primer dalam penelitian ini adalah wawancara pada pengawas TK/PAUD Dinas Pendidikan Kecamatan Driyorejo, guru dan kepala PAUD di Kabupaten Gresik.

\section{Data sekunder}

Data sekunder adalah sumber data yang diperoleh secara tidak langsung dari informan di lapangan, seperti dokumen dan sebagainya. Dokumen tersebut dapat berupa buku-buku dan literature lainnya yang berkaitan serta berhubungan dengan masalah yang sedang diteliti. Data sekunder dalam penelitian ini berupa dokumendokumen yang berhubungan dengan pelaksanaan supervisi oleh pengawas seperti program pengawasan dan laporan program pengawasan.

\section{Lokasi dan Waktu Penelitian}

Penelitian ini dilakukan di Dinas

Pendidikan Kecamatan Driyorejo Kabupaten Gresik dan seluruh Anggota Himpaudi pada Maret 2018.

\section{Instrumen Penelitian}

Instrumen

merupakan suatu alat yang digunakan untuk mengukur fenomena alam maupun sosial yang diamati (Sugiyono, 2009: 305). Kedudukan peneliti di dalam penelitian kualitatif sebagai perencana, pelaksana pengumpulan data, analisis, penafsir data, dan pada akhirnya peneliti menjadi pelapor hasil penelitiannya. Dalam penelitian kualitatif yang menjadi instrumen atau alat penelitian adalah peneliti itu sendiri (human instrument)

Instrumen penelitian adalah alat atau fasilitas yang digunakan oleh peneliti dalam mengumpulkan data agar pekerjaannya lebih mudah dan hasilnya lebih baik, dalam arti: cepat, lengkap, dan sistematis sehingga lebih mudah diolah (Arikunto: 2006: 149).

\section{Teknik Pengumpulan Data}

Teknik pengumpulan data adalah hal utama dalam penelitian, karena tujuan utama dari penelitian adalah mendapatkan data. Tanpa mengetahui teknik pengumpulan data maka peneliti tidak akan mendapat data yang memenuhi standar data yang ditetapkan. Menurut Sugiyono (2010: 401) dalam penelitian kualitatif dikemukakan bahwa pengumpulan data yang utama adalah observasi partisipasi, wawancara mendalam studi dokumentasi dan triangulasi.

$$
\text { Pengumpulan data dalam }
$$

penelitian ini dilakukan dengan beberapa teknik yang sesuai dengan data yang diperlukan. Data yang 
diperlukan tersebut sesuai dengan

tujuan penelitian. Dalam mengumpulkan data-data tersebut maka peneliti menggunakan teknik Wawancara, Observasi, dan Dokumentasi.

\section{Teknik Analisis Data}

Analisis data adalah proses mencari dan menyusun secara sistematis data yang diperoleh dari hasil wawancara, catatan lapangan, dan bahan lain sehingga dapat mudah dipahami dan temuannya dapat diinformasikan kepada orang lain. Analisis data dilakukan dengan cara mengorganisasikan data ke dalam kategori, menjabarkan ke dalam unit-unit, melakukan sintesa, menyusun ke dalam pola, memilih mana yang penting yang akan dipelajari, dan membuat kesimpulan sehingga mudah dipahami oleh orang lain (Sugiyono, 2010: 334).

Dalam penelitian ini teknik yang digunakan adalah teknik deskriptif, sehingga laporan dalam penelitian ini dinyatakan dalam bentuk narasi yang bersifat deskriptif dari data berbagai peristiwa.

\section{HASIL DAN PEMBAHASAN}

Hasil Penelitian

Dari paparan di atas maka dapat ditarik kesimpulan bahwa pengawas sekolah adalah jabatan fungsional yang berkedudukan sebagai pelaksana teknis untuk melakukan pengawasan pendidikan terhadap sejumlah sekolah tertentu yang ditunjuk atau ditetapkan dalam upaya meningkatkan proses dan hasil belajar untuk mencapai tujuan pendidikan. Dalam penelitian ini pengawas sekolah yang dimaksud adalah pengawas TK/PAUD. Pengawas TK/PAUD adalah pengawas sekolah yang mempunyai tugas, tanggungjawab serta wewenang secara penuh untuk melakukan tugas pengawasan pada sejumlah sekolah tertentu dalam wilayah tertentu baik negeri maupun swasta di tingkat TK dan PAUD. Dalam penelitian ini akan lebih dibahas mengenai pelaksanaan tugas pengawas TK/PAUD pada tingkat TK

$\begin{array}{llr}\text { Dalam } & \text { kedudukan } & \text { dan } \\ \text { fungsinya } & \text { pengawas adalah } \\ \text { penanggung jawab utama dalam }\end{array}$
kegiatan pemberian pembinaan sekolah. Menurut Peraturan Menteri Negara Pendayagunaan Aparatur Negara dan Reformasi Birokrasi Nomor 21 Tahun 2010, pasal 5 bahwa Tugas pokok Pengawas Sekolah adalah melaksanakan pengawasan akademik dan pengawasan manajerial pada satuan pendidikan yang meliputi penyusunan program, pelaksanaan pembinaan, pemantauan pelaksanaan 8 (delapan) Standar Nasional Pendidikan, penilaian, pembimbingan dan pelatihan professional guru, evaluasi hasil pelaksanaan program pengawasan, dan pelaksanaan program kepengawasan di daerah khusus. 
Keputusan Mendikbud nomor 020/U/1998 tentang petunjuk teknis pelaksanaan jabatan fungsional pengawas sekolah dan angka kreditnya, dapat dikemukakan mengenai tugas pokok dan tanggung jawab pengawas sekolah sebagai berikut:

1. Melaksanakan pengawasan penyelenggaraan pendidikan di sekolah sesuai dengan penugasannya pada TK, PAUD, SLB, SLTP dan SLTA.

2. Meningkatkan kualitas proses belajar-mengajar atau bimbingan dan hasil prestasi belajar/bimbingan siswa dalam rangka mencapai tujuan pendidikan.

\section{Dalam Panduan Pelaksanaan}

Tugas Pengawas Sekolah/Madrasah (Direktorat Tenaga Kependidikan, 2009: 20), Tugas pokok pengawas sekolah/madrasah mencakup enam dimensi utama, yakni mensupervisi, memberi nasehat, memantau, membuat laporan, mengkoordinir, dan memimpin. Jabatan fungsional pengawas sekolah telah mengamanatkan agar pengawas melakukan tugas pembinaan dan penilaian baik secara teknis maupun administrasi pendidikan dalam rangka untuk meningkatkan mutu pendidikan. Menurut keputusan Menpan No. 118/1996 Bab II Pasal 3 ayat 1 , rincian tugas pokok pengawas sekolah adalah sebagai berikut:
1. Merumuskan rancangan program tahunan pengawasan sekolah tingkat kabupatan atau Kabupaten madya.

2. Menyusun program semester pengawasan sekolah yang sudah menjadi tanggung jawabnya.

3. Menyusun kisi-kisi dalam rangka penyusunan soal atau instrument penelitian.

4. Melaksanakan penilaian, pengolahan dan analisis data hasil belajar tau bimbingan siswa dan kemampuan guru.

5. Mengumpulkan dan mengolah data sumber daya pendidikan, proses belajar mengajar atau bimbingan dan lingkungan sekolah yang berpengaruh pada perkembangan dan hasil belajar atau bimbbingan siswa.

6. Melaksanakan analisis komprehensif hasil belajar atau bimbingan siswa dengan memperhitungkan berbagai faktor sumber daya pendidikan yang lebih kompleks termasuk koreksi kemampuan guru dengan hasil belajar atau bimbingan belajar.

7. Memberikan arahan dan bimbingan kepada guru tentang pelaksanaan proses belajar mengajar atau bimbingan siswa.

8. Memberikan saran untuk peningkatan kemampuan 
profesional guru kepada pimpinan instansi terkait.

9. Menyusun laporan hasil pengawasan sekolah persekolah.

10. Memberikan contoh pelaksanaan tugas guru dalam melaksanakan proses belajar mengajar atau bimbingan siswa.

11. Melaksanakan evaluasi hasil pengawasan seluruh sekolah yang menjadi tanggung jawabnya.

12. Membina pelaksanaan pengelolaan sekolah.

13. Memantau dan membimbing pelaksanaan UAS/UAN.

14. Memberikan saran penyelesaian kasus khusus di sekolah.

15. Memberikan bahan penilaian dalam angkaakreditasi sekolah swasta.

16. Melaksanakan evaluasi hasil pengawasan permata pelajaran atau bimbingan siswa dari sekolah.

17. Melaksanakan kegiatan karya tulis atau karya ilmiah dalam bidang pendidikan.

18. Menyusun pedoman pengawasan sekolah.

19. Menyusun petunjuk teknis pengawasan sekolah.

\section{Pembahasan}

$\begin{array}{ccc}\text { Pada } & \text { hakikatnya } & \text { supervisi } \\ \text { merupakan } & \text { keseluruhan } & \text { kegiatan } \\ \text { membantu } & \text { pengelola } & \text { lembaga }\end{array}$

pendidikan

meningkatkan kemampuannya dalam mengelola lembaganya. Secara operasional, kegiatan supervisi pengawas merupakan serangkaian kegiatan membantu kepala sekolah mengembangkan kemampuannya mengelola sekolah, atau membantu guru mengembangkan kemampuannya mengelola proses belajar mengajar. Dalam kegiatan supervisi, didalamnya terdapat kegiatan pengawas dalam mengukur unjuk kerja guru, namun tujuannya bukan untuk menilai kemampuan guru semata, melainkan untuk mengetahui keterbatasan kemampuannya dalam rangka meningkatkan kemampuan guru.

Dengan demikian supervisi merupakan serangkaian kegiatan membantu personal sekolah dalam meningkatkan kemampuannya. Secara lebih umum dapat diartikan bahwa program supervisi yang dilaksanakan oleh pengawas berfungsi sebagai kegiatan dalam memberikan pembinaan atau penilaian terhadap teknis pendidikan dan administrasi pendidikan di sekolah binaan dalam rangka meningkatkan kualitas pendidikan.

Dalam rangka penelitian ini, supervisi yang dilaksanakan oleh penilik, serta kesulitan yang dihadapi oleh pengawas pada waktu melaksanakan supervisi. Sampel dari penelitian ini adalah 12 orang pengawas akademik dan 42 orang guru TK/PAUD di Kecamatan 
Driyorejo Selanjutnya dalam penelitian ini akan dibahas kesulitan pengawas dalam melakukan supervisi akademik, kemudian hal tersebut akan di cross check oleh guru-guru TK/PAUD di Kecamatan Driyorejo, sehingga dapat diketahui gap diantara keduanya.

Supervisi merupakan suatu usaha untuk memperbaiki, mengarahkan dan mengembangkan guru dan personil sekolah lainnya untuk mengembangkan situasi belajar mengajar. Apabila dilihat dari ruang lingkupnya maka pelaksanaan supervisi pendidikan terdiri dari dua kegiatan yaitu akademik dan administratif. Untuk supervisi akademik merupakan supervisi yang menitikberatkan pengamatan pada masalah akademik yang langsung berada dalam lingkup kegiatan pembelajaran yang dilakukan oleh guru untuk membantu peserta didik ketika sedang dalam proses belajar.

Menurut pengawas, dalam hal penyusunan program dan jadwal supervisi yang dilaksanakan guru, maka akan diamati dan dicermati halhal sebagai berikut:

1. Penyusunan program dan jadwal supervisi.

2. Merumuskan pelaksanaan supervisi akademik.

3. Merumuskan sasaran supervisi akademik.

4. Merumusan jadwal kegiatan supervisi akademik.
Dari beberapa keterangan pengawas tersebut, diketahui bahwa pengawas yang menjadi supervisi akademik di wilayah Driyorejo menyatakan bahwa telah melaksanakan kegiatan supervisi akademik, hasil pencapaian dari pelaksanaan pengawas supervisi akademik akan di cross-check dengan hasil penilaian dari guru.

\section{PENUTUP}

\section{Kesimpulan}

Berdasarkan data yang telah dikumpulkan dan dilakukan analisis pembahasan mengenai pelaksanaan supervisi PAUD oleh pengawas Dinas Pendidikan kecamatan Driyorejo Di Himpaudi, maka dapat disimpulkan bahwa pelaksanaan supervisi PAUD yang dilakukan pengawas Dinas Pendidikan kecamatan Driyorejo meliputi supervisi manajerial dan akademik.

1. Supervisi manajerial oleh pengawas TK/PAUD Dinas Pendidikan Kecamatan Driyorejo pada TK dilakukan dengan kunjungan sekolah dan masih dominan pada penilaian kinerja kepala sekolah, sarana prasarana, dan kelengkapan administrasi sekolah.

2. Pada pelaksanaan supervisi akademik Di Himpaudi juga dominan pada kegiatan penilaian kinerja guru dalam melaksanakan pembelajaran seperti kelengkapan RKM, RHK, RKT. Pelaksanaan supervisi 
akademik belum secara rutin dan jadwal supervisi belum dilaksanakan sesuai yang telah dibuat pengawas TK/PAUD sebelumnya.

3. Teknik supervisi yang dilakukan oleh pengawas TK/PAUD Dinas Pendidikan Kecamatan Driyorejo pada Himpaudi adalah dengan teknik secara individu dan teknik secara kelompok. Dalam supervisi manajerial teknik individu yang dilakukan adalah dengan mengunjungi sekolah, melakukan percakapan individu pada kepala sekolah, sedangkan teknik secara kelompok dilakukan dengan pembinaan KKKS (Kelompok Kerja Kepala Sekolah) pada gugus PAUD. Pada supervisi akademik teknik individu yang digunakan adalah dengan melakukan kunjungan sekolah, kunjungan kelas, kunjungan antar kelas dan percakapan pribadi. Untuk teknik kelompok yang dilakukan pada supervisi tersebut adalah dengan melalui kegiatan KKG (Kelompok Kerja Guru) pada gugus PAUD.

\section{DAFTAR PUSTAKA}

Arikunto, Suharsimi. 2004. DasarDasar Supervisi. Jakarta: PT Rineka Cipta.

Arikunto, Suharsimi. 2006. Prosedur Penelitian Suatu
Pendekatan Praktek. Jakarta: PT Rineka Cipta.

Peraturan Menteri Pendidikan Nasional No. 13 Tahun 2007 tentang Standar Pengawas Sekolah/Madrasah.

Peraturan Menteri Pendidikan Dan Kebudayaan Republik Indonesia Nomor 137 Tahun 2014 Tentang Standar Nasional Pendidikan Anak Usia Dini

Peraturan Pemerintah Republik Indonesia No. 19 Tahun 2005 tentang Standar Nasional Kependidikan.

Peraturan Menteri Pendidikan dan Kebudayaan Nomor 38 Tahun 2013 Tentang Petunjuk Teknis Jabatan Fungsional Penilik dan angka kreditnya.

Menteri Pendayagunaan Aparatur Negara. 1996. Keputusan Menteri Negara Pendayagunaan Aparatur Negara Nomor 118/1996 tentang Jabatan Fungsional Pengawas Sekolah dan Angka Kreditnya.

Moleong, L.J. 2011. Metodologi Penelitian Kualitatif Edisi Revisi. Bandung: PT. Remaja Rosdakarya

Moleong, L.J. 2008. Metode Penelitian kualitatif, Remaja Rosda Karya, Bandung,

Sugiyono. 2009. Metode Penelitian Kuantitatif, Kualitatif dan R\&D, Bandung : Alfabeta.

Sugiyono. 2010. Metode Penelitian Pendidikan Pendekatan Kuantitatif, kualitatif, dan R\&D. Bandung: Alfabeta. 